\title{
ENVIRONMENTAL POLLUTION PROBLEM DUE TO ELECTRONIC WASTES
}

El-Ramly, Salwa, H. A. ${ }^{(1)}$; Mohammed, M. A. ${ }^{(2)}$ and Farahat, M. A. Z 1) Faculty of Engineering, Ain Shams University 2) Faculty of Commerce, Ain Shams University

\begin{abstract}
Electronic devices are intended to create our existence better-off and meeker; however they have harmless materials, their removal besides reprocessing converts a healthiness terrible. The situation had entered each part of our existence besides most of us not ensure whatever occurs to these devices after we remove otherwise upgrading. The usage of these devices had increased nowadays also proportion, the amount of electronic wastes that are getting rid of, stay rising quickly through civilization. E-waste stays a developing difficult specified the sizes of e-waste being increasing plus the content of both toxic and worthy materials in them. This fast increasing waste flow is go faster due to the universal corner for personal computers (PC) is away from fullness also the normal lifetime of a PC is declining speedily.

Key Words: Electronic Wastes, Fedral Environment Protection Agency, Management of Solid Wastes.
\end{abstract}

\section{INTROUDUCTION}

Through the previous twenty years, the international drive of electrical and electronic equipment (EEE) keeps to become larger in an increasingly way, although the lifetime of these produces being smaller. Perhaps, the quantity of electrical produces will keep increasing, and microprocessors will be used in ever increasing numbers in daily objects. The producing of EEE is one of the wildest industrial doings. Fast commercial growing, duplicated 
with development and an increasing request for customers, has improved both the consuming and the producing of EEE (Balabanic et al., 2011)

Such modern type of waste is showing an important defy in throwing away and recycling to both improved and improving countries. (Cui and Zhang ,2008).

E-waste hold worthy mineral $(\mathrm{Cu}$, platinum group) as well as potential environmental pollutants, specially $\mathrm{Pb}, \mathrm{Sb}, \mathrm{Hg}, \mathrm{Cd}, \mathrm{Ni}$, polybrominated diphenyl ethers (PBDEs), and polychlorinated biphenyls (PCBs). Firing Ewaste might produce dioxins, furans, polycyclic aromatic hydrocarbons (PAHs), polyhalogenated aromatic hydrocarbons (PHAHs), and hydrogen chloride. Most E-waste is disposed in landfills. Effective reprocessing technology, which improves the valued materials with less environmental side effect, is costly. (Robinson,2009).

Information and communications technology (ICT) and computer Internet networking had entered almost each part of our current life. The fast growing in ICT had led to a development in the capacity of computers but concurrently to a reduction in the produces lifetime as a result of which more and more huge amounts of waste electrical and electronic equipment (ewaste) are produced per annum. ICT growth in most developing countries, mainly in Africa, hinge on more on secondhand or renewed EEEs most of which are introduced starved of testing for working. As a result large amounts of e-waste are currently being managed in these nations. The defy fronting the emerging nations in e-waste management include: an absence of infrastructure for suitable, waste management, an absence of statute dealing 
exactly with e-waste, an absence of any framework for end-of-life (EoL) product take-back or implementation of extended producer responsibility (EPR). (Osibanjo and Nnorom ,2007).

being increasing plus the content of both toxic and worthy materials in them. This fast increasing waste flow is go faster due to the universal corner for personal computers (PC) is away from fullness also the normal lifetime of a PC is declining speedily. The lifetime of central processing units (CPU) had lowered as of 4- 6 years in 1997 to 2 years in 2005 (Arwidsson and Allard ,2009)

\section{THE PROBLEM}

Information and communications technology (ICT) and computer Internet networking had entered almost each part of our current life.

The fast growing in ICT had led to a development in the capacity of computers but concurrently to a reduction in the produces lifetime as a result of which more and more huge amounts of waste electrical and electronic equipment (e-waste) are produced per annum.

E-waste consists of a large variety of materials, some of contaminate the environment and threaten human health not appropriately managed.

\section{THE TARGET}

Much effort to adopt green strategies is initiated by individuals or non governmental institutions which do not often receive much support from their governments. By supporting these organizations, the government will help to reduce E-waste. 
Manufacturers need to place tags on computers that show their degree of greenness following established guidelines such as AAA (100\% recyclable), AA (50\% recyclable), A ( $25 \%$ recyclable), etc. This will inform decisions on which computers to purchase.

Manufacturers and Suppliers of computers need to work together with local governments and individuals to promote green IT, by adhering to legislation.

\section{METHODOLOGY}

Show how dangerous of electronic waste (E-Waste) and how IT Generation Globally.

Show E-waste Composition.

Showing concerted hazardous materials related to E-waste and their health effects.

Study about E-Waste management in Egypt.

\section{LITERATURE}

What is E- waste: Electronic waste generally recognized as e-waste is the public name specified for electronic produces close to or at the end of its useful life. E-waste in short is a public term Sit many forms of electric and electronic equipment that have Stop to be of any worth to their owners. (Needhidasan et al., 2014).

The expression electronic waste is only a new structure, as devices of higher technology only began to be formed near the latter half of the 20th century. Previously the 1970s, there was little produce of these complex 
items. Each year, more new devices are formed, and more new devices are thrown out. This began in the most developed countries such as the United States and Japan, leading the technological revolt but also leading the electronic pollution uprising as well. And with a huge inhabitants, America. (Uddin, 2012).

As a communal and unofficial expression, electronic waste (e-Waste) is generally, refers to any white goods, consumer and business electronics, and information technology hardware that are in the end of its useful life. Exactly, Puckett et al., (2002) defined e-waste as "a broad and growing range of electronic devices ranging from large household devices such as refrigerators, air conditions, cell phones, personal stereos, and consumer electronics to computers which had been discarded by their users". According to SinhaKhetriwal et al., (2002) "E-Waste can be classified as any electrical powered appliance that has reached its end-of-life".

E-waste Generation Globally: Industrialized and developed nations are the main producers of e-waste. According to the United States Environmental Protection Agency USEPA, the US is the largest e-waste producer in the world today, generating 3.16 million tons in 2008. (Hossain et al., 2015).

In addition, 5 million tons were in storage with 2.37 million tons ready for disposal in 2009, and that represents a $120 \%$ increase from 1999. The EU (European Union) on generated 8.9 million tons in 2010 and that rate is increasing by $3-5 \%$ yearly, and is projected to be 12 million tons by 2020 . (Herat and Agamuthu ,2012)

The rapidly increasing trend of e-waste production is rising in the biggest and fastest growing economies such as China and India. China is 
ranked second after the US and generated 2.3 million tons of e-waste in 2010 and is predicted to have a

Surplus by 2020. In addition, India generated 400,000 tons in 2011. (Jain,2010)

The European Union is also considered to be one of the biggest producers of e-waste. In 2010, the EU produced 8.9 million tons of e-waste. (Zoeteman et al., 2010) .This 1-3\% of the total MSW (solid wastes) in the US, a 16-28\%increase every five years, which is 3-times faster than MSW generation. A recent study found that annually, 5 to 7 million tons of e-waste is generated in the EU with a per capita of $14-15 \mathrm{~kg}$ and is expected to increase at a 3 to $5 \%$ annual growth rate. (Guidelines for e-waste management in Bangladesh, 2012)

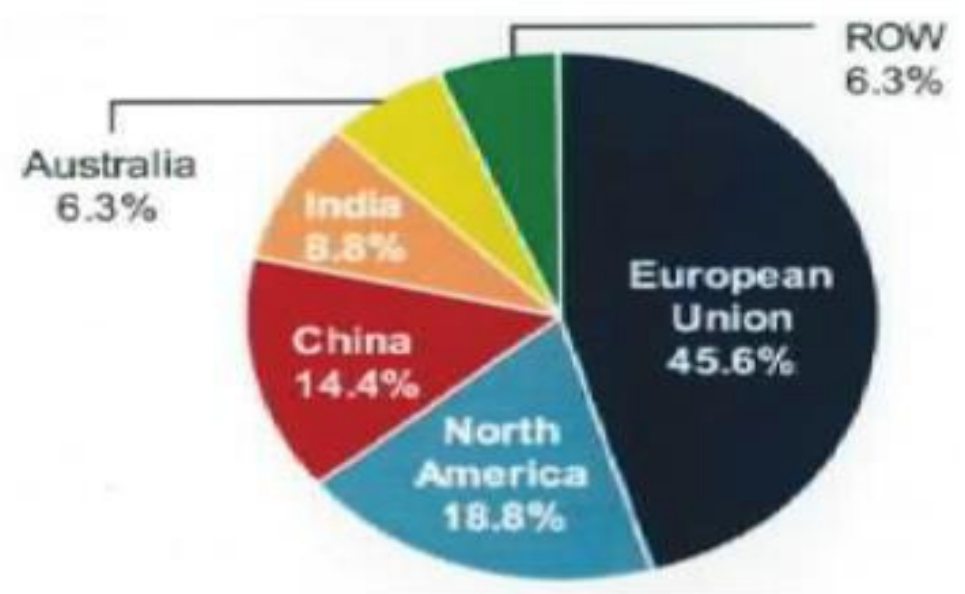

Source: UNEP, European Commission, BCC, 2013.

Figure (1): The distribution of global e-waste generated by region with European Union having the largest section followed by North America, China, India, Australia and the rest of the world (ROW) respectively. 
Table (1): Concerted hazardous materials related to E-waste and their health effects. Source: (Kiddee et al., 2013)

\begin{tabular}{|c|c|c|}
\hline materials & usage in e-waste & Health effect \\
\hline Antimony (Sb) & $\begin{array}{l}\text { a melting agent in CRT } \\
\text { glass, plastic computer } \\
\text { housings and a solder } \\
\text { alloy in cabling }\end{array}$ & $\begin{array}{l}\text { Antimony has been classified } \\
\text { as a carcinogen. It can cause } \\
\text { stomach pain, vomiting, } \\
\text { diarrhoea and stomach ulcers } \\
\text { through inhalation of high } \\
\text { antimony levels over a long } \\
\text { time period }\end{array}$ \\
\hline Arsenic (As) & $\begin{array}{l}\text { Gallium arsenide is } \\
\text { used in light emitting } \\
\text { diodes }\end{array}$ & $\begin{array}{l}\text { It has chronic effects that } \\
\text { cause skin disease and lung } \\
\text { cancer and impaired nerve } \\
\text { signalling }\end{array}$ \\
\hline Barium $(\mathrm{Ba})$ & $\begin{array}{l}\text { Sparkplugs, fluorescent } \\
\text { lamps and CRT gutters } \\
\text { in vacuum tubes }\end{array}$ & $\begin{array}{l}\text { Causes brain swelling, muscle } \\
\text { weakness, damage to the heart, } \\
\text { liver and spleen though short- } \\
\text { term exposure }\end{array}$ \\
\hline Beryllium $(\mathrm{Be})$ & $\begin{array}{l}\text { Power supply boxes, } \\
\text { motherboards, relays } \\
\text { and finger clips }\end{array}$ & $\begin{array}{l}\text { Exposure to beryllium can lead } \\
\text { to beryllicosis, lung cancer and } \\
\text { skin disease. Beryllium is a } \\
\text { carcinogen }\end{array}$ \\
\hline $\begin{array}{l}\text { Brominated flame etardants } \\
\text { (BFRs): (polybrominated } \\
\text { biphenyls (PBBs), } \\
\text { polybrominated diphenyl } \\
\text { ethers } \\
\text { (PBDEs) and } \\
\text { tetrabromobisphenol } \\
\text { (TBBPA) }\end{array}$ & $\begin{array}{l}\text { BFRs are used to reduce } \\
\text { flammability in printed } \\
\text { circuit boards and } \\
\text { plastic housings, } \\
\text { keyboards and cable } \\
\text { insulation }\end{array}$ & $\begin{array}{l}\text { During combustion printed } \\
\text { circuit boards and plastic } \\
\text { housings emit toxic vapours } \\
\text { known to cause hormonal } \\
\text { disorders }\end{array}$ \\
\hline Cadmium $(\mathrm{Cd})$ & $\begin{array}{l}\text { Rechargeable NiCd } \\
\text { batteries, } \\
\text { semiconductor chips, } \\
\text { infrared detectors }\end{array}$ & $\begin{array}{l}\text { Cadmium compounds pose a } \\
\text { risk of irreversible impacts on } \\
\text { human health, particularly the } \\
\text { kidneys }\end{array}$ \\
\hline Chlorofluorocarbons (CFCs) & $\begin{array}{l}\text { Cooling units and } \\
\text { insulation foam }\end{array}$ & $\begin{array}{l}\text { These substances impact on } \\
\text { the ozone layer which can lead } \\
\text { to greater incidence of skin } \\
\text { cancer }\end{array}$ \\
\hline
\end{tabular}


J. Environ. Sci.

Institute of Environmental Studies and Research - Ain Shams University

\section{Con. Table(1)}

\begin{tabular}{|c|c|c|}
\hline materials & usage in e-waste & Health effect \\
\hline $\begin{array}{l}\text { Hexavalent } \\
\text { chromium/chromium VI (Cr } \\
\text { VI) }\end{array}$ & $\begin{array}{l}\text { Plastic computer } \\
\text { housing, cabling, hard } \\
\text { discs and as a colourant } \\
\text { in pigments }\end{array}$ & $\begin{array}{l}\text { Is extremely toxic in the } \\
\text { environment, causing DNA } \\
\text { damage and permanent eye } \\
\text { impairment }\end{array}$ \\
\hline Lead $(\mathrm{Pb})$ & $\begin{array}{l}\text { Solder, lead-acid } \\
\text { batteries, cathode ray } \\
\text { tubes, cabling, printed } \\
\text { circuit boards and } \\
\text { fluorescent tubes }\end{array}$ & $\begin{array}{l}\text { Can damage the brain, nervous } \\
\text { system, kidney and } \\
\text { reproductive system and cause } \\
\text { blood disorders. Low } \\
\text { concentrations of lead can } \\
\text { damage the brain and nervous } \\
\text { system in foetuses and young } \\
\text { children. The accumulation of } \\
\text { lead in the environment results } \\
\text { in both acute and chronic } \\
\text { effects on human health }\end{array}$ \\
\hline Mercury (Hg) & $\begin{array}{l}\text { Batteries, backlight } \\
\text { bulbs or lamps, flat } \\
\text { panel displays, switches } \\
\text { and thermostats }\end{array}$ & $\begin{array}{l}\text { Mercury can damage the brain, } \\
\text { kidneys and foetuses }\end{array}$ \\
\hline $\begin{array}{l}\text { Polychlorinated biphenyls } \\
\text { (PCBs) }\end{array}$ & $\begin{array}{l}\text { Condensers, } \\
\text { transformers and heat } \\
\text { transfer fluids }\end{array}$ & $\begin{array}{l}\text { PCBs cause cancer in animals } \\
\text { and can lead to liver damage in } \\
\text { humans }\end{array}$ \\
\hline Polyvinyl chloride (PVC) & $\begin{array}{l}\text { Monitors, keyboards, } \\
\text { cabling and plastic } \\
\text { computer housing }\end{array}$ & $\begin{array}{l}\text { PVC has the potential for } \\
\text { hazardous substances and toxic } \\
\text { air contaminants. The } \\
\text { incomplete combustion of } \\
\text { PVC release huge amounts of } \\
\text { hydrogen chloride gas which } \\
\text { form hydrochloric acid after } \\
\text { combination with moisture. } \\
\text { Hydrochloric acid can cause } \\
\text { respiratory problems }\end{array}$ \\
\hline
\end{tabular}




\section{Study about E-Waste management in Egypt:}

The Ministry of Environment management project: The Egyptian

Ministry of Environment began in two projects to manage electronic wastes, as pair as Professor Essam Abdel-Aziz The Electronic Waste Management Project Manager Branching from the national program for solid waste management They will begin in two projects:

UNDP (United Nation Development Program): Protection of human health and the environment from unintentional emissions from persistent organic pollutants resulting from the combustion and open burning of health-care waste and electronic:

This project will deal with five points of E-Wastes:

1- Legislation.

2- The current situation.

3- Trade places.

4- Methods of trading5-Companies working in this field.

Second project: SRI (Sustainable Recycling Industries): Making Switzerland's efforts vigorous for the transfer of expertise to developing countries in the field of recycling of electronic waste since 2003 and in 2012 was Sustainable recycling capacity building in the same developing countries field industries program launch, and each of the plants Swiss federal Science article and Technology and the Association of the Universal Forum of resources to the implementation of the program and that funded by the Secretariat of economic Affairs. A partnership was established between the Swiss side and the Egyptian government imitators in recycling Sustainable Industries and the Ministry of Communications and information technology 
program in Egypt, where they signed an agreement whereby the integration of the support and participation of small enterprises and medium-sized recycling in sustainable through the implementation of (SRI) project and extends the time frame for the project to employees by the end of 2017.

The project aims to improve the local talent to institutions public and private sector and the formal and informal in order to restore sustainable recycling and the accompanying rational management and security resources secondary non-renewable and represents a major outputs of the project, which will in turn create jobs.

Building technology companies: The project seeks to develop cooperation agreements and action plans that will facilitate the material support and administrative, legal and technical sectors of formal and informal, through incubators youth program for the recycling of electronic waste, including incubators Services to provide technical information and training of trainers as well as creating linkages and partnerships techs and test how the facility of small capacity and medium-sized standards commitment and follow-up operation to ensure long-term sustainability.

Put calibrator and standard specifications: This project supports national initiatives aimed at establishing the legal framework and the criteria necessary for the implementation of the sustainable recycling of residues The Electronic addition to providing the necessary support to the authorities to determine the training and the granting of leave to one independent entities to carry out the assessment of adherence to standards. 
Establish a system to fund the recycling industries: The project to develop the recovery of electronic devices based on models liarits Extended Producer stimulus and to develop mechanisms which will ensure the long-term payoff for recycling in general.

The Centre for Environment and Development for the Arab Region and Europe (CEDARE) in collaboration with the Ministry of Communications and Information Technology, Egypt and international experts of the company (Sofiz) Switzerland implementation of the project in coordination with the ministries of environment, trade and industry and the project will join efforts with a number of other existing projects on electronic waste treatment, notably UNDP United Nations and other.

\section{A company work in E-Waste management in Egypt:}

\section{International technology group (ITG):}

Mission: To share in Green \& Clean environment in Egypt \& increase numbers of Recycling in safe \& secure ways by collecting old IT products like Server, Desktop, Laptop, Telecommunication , Mobile , Printer , Network ,etc. for secure \& clean recycling and issue Certificate of Disposal for your E- Scrap.

Story: Remove and Recycle your old IT equipment. Like Server, Computer, Laptop, Mobile , Printer , photocopier , Fax ,Network ,Communication Equipment's , accessories , etc. all you need: To send us Email your full inventory of IT Scrap to eerc@mail.com then we will contact you within 48 hours Max .To confirm collection and the process for disposal. 
About: We're the first Factory in Egypt for E-waste Recycling scrap IT Equipments like Computer, Laptops, Server, Monitor, Mobile, cable, printer, etc.

Products: E-Waste Recycling like Scrap computer ,Server, Laptop , Mobile, Monitor, Photocopier, printer , Cable ,Fax machine , Network equipment , communication devices ,etc.

\section{E-waste recycling items:}

\section{1-Scrap Desktop Computers}

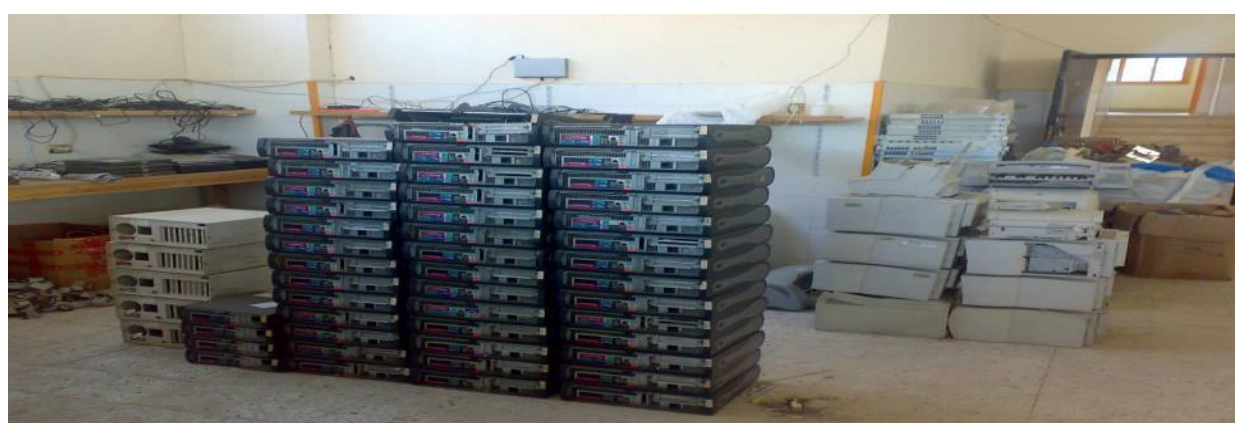

Figure 1: Scrap Desktop Computers

\section{2- Scrap Monitors}

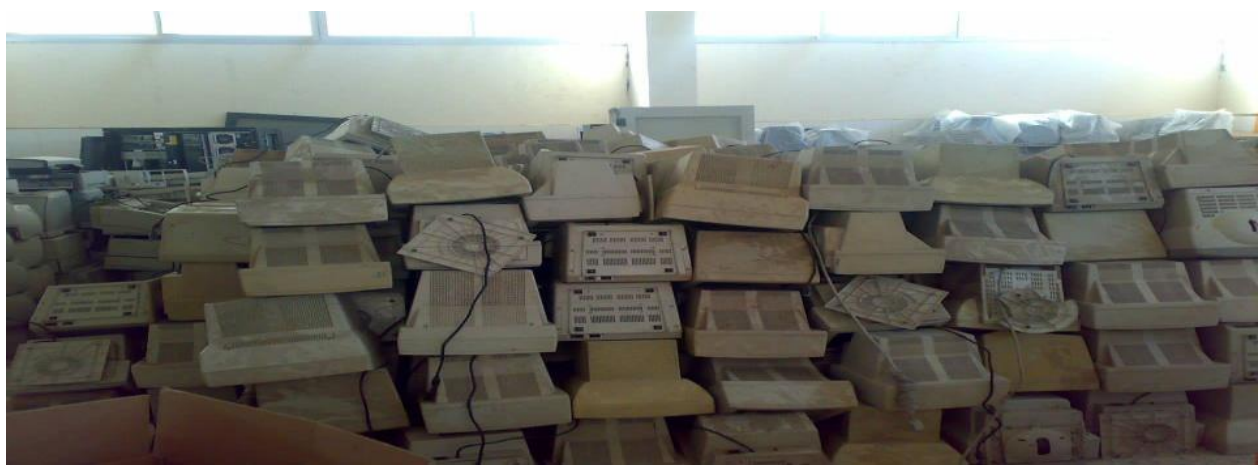

Figure 2: Scrap Monitors 


\section{3-Scrap Computer}

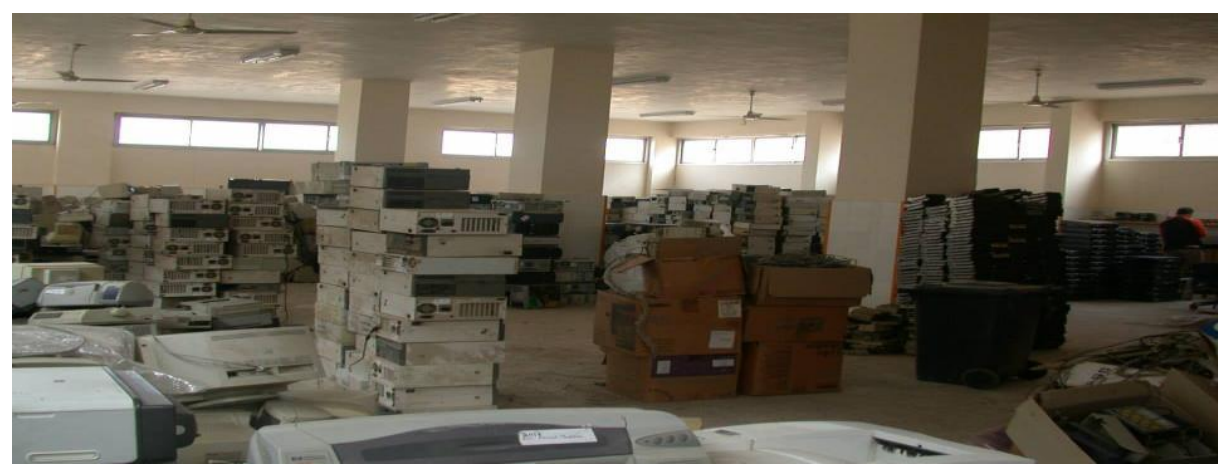

Figure 3: Scrap Monitors

\section{4-Scrap Network}

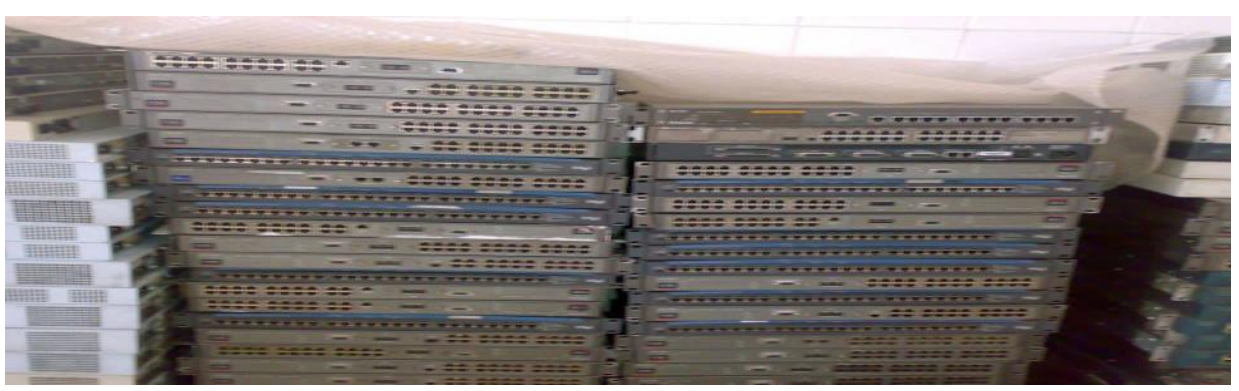

Figure 4: Scrap Network

\section{5-Scrap Laptops}

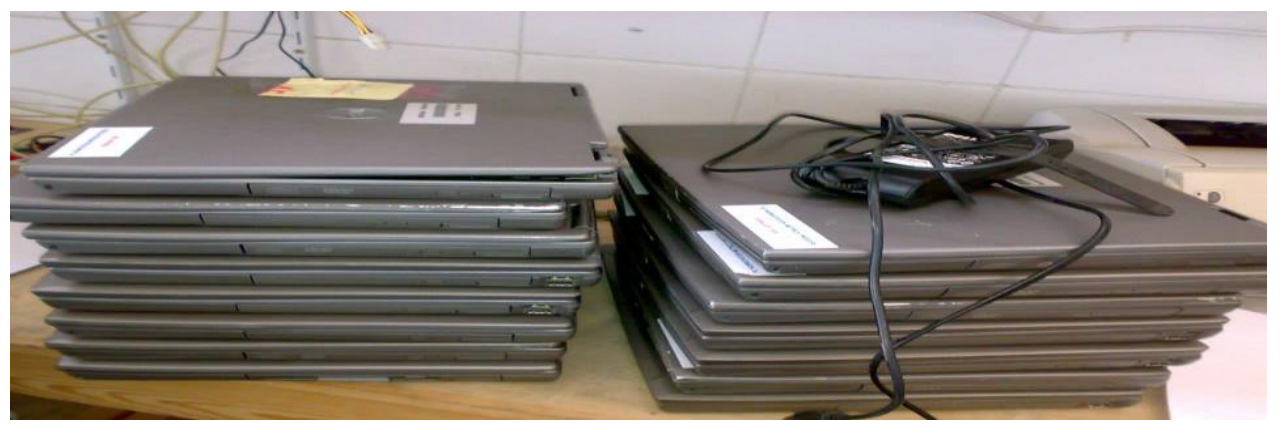

Figure 5: Scrap Network 


\section{6-Scrap Cable:}

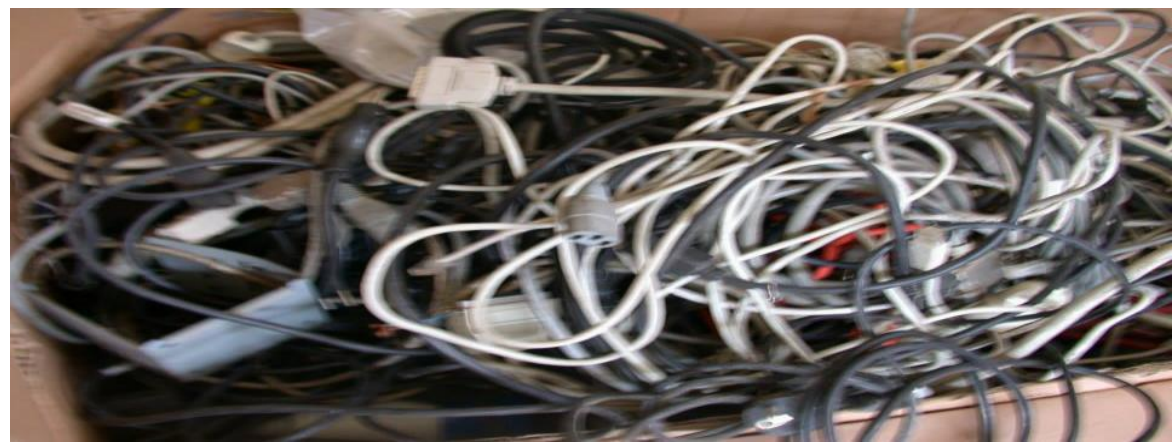

Figure 6: Scrap Cable

\section{7-Scrap PCB's (printed circuit Board):}

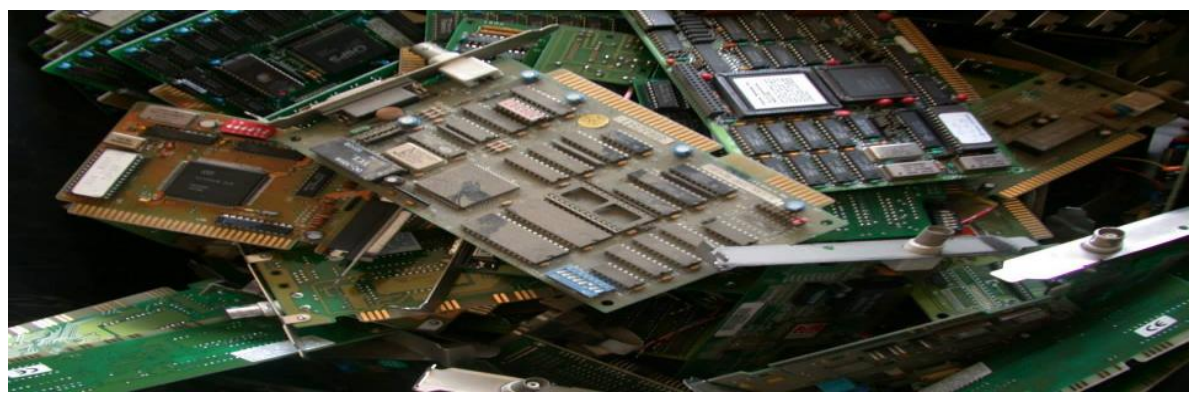

Figure 7: Scrap printed circuit Board

\section{8- Scrap server:}

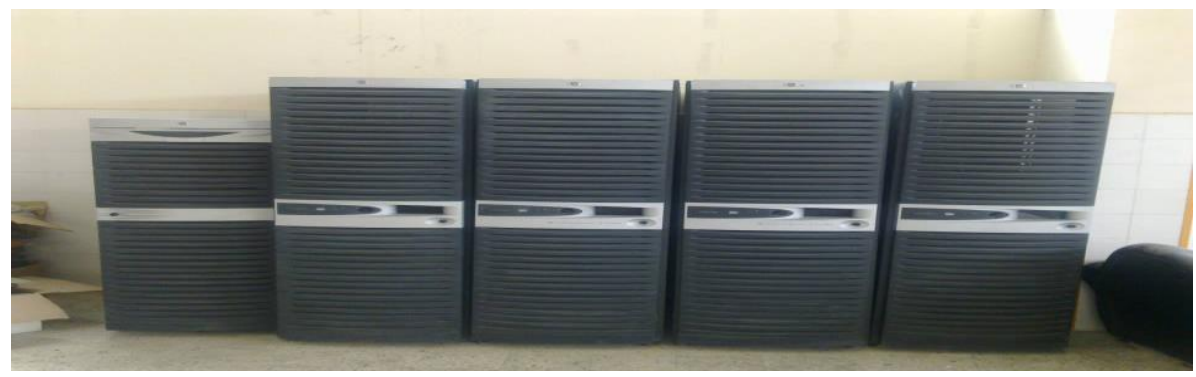

Figure 8: Scrap server 


\section{9- Disassemble Line Production}

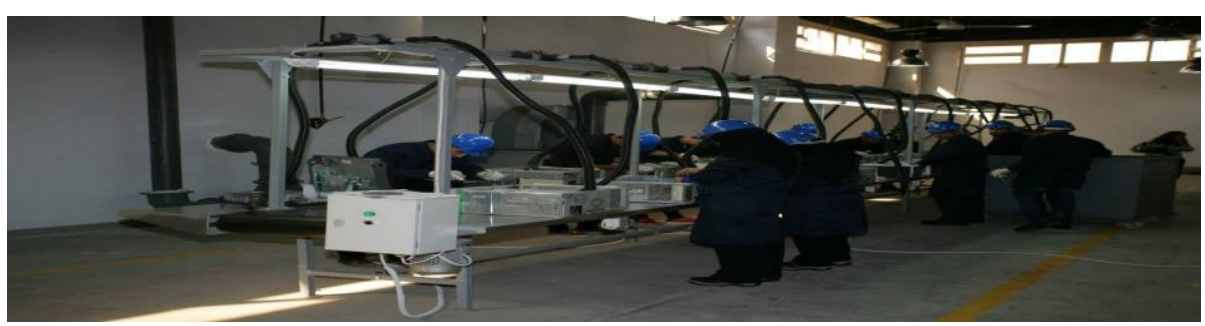

Figure 9.A: Disassemble Line Production

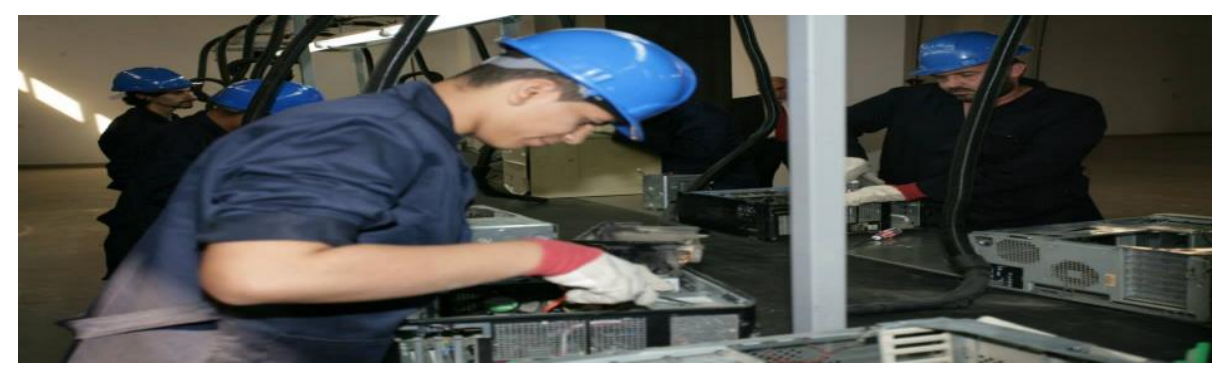

Figure 9B: Disassemble Line Production

10- E-waste recycling Line

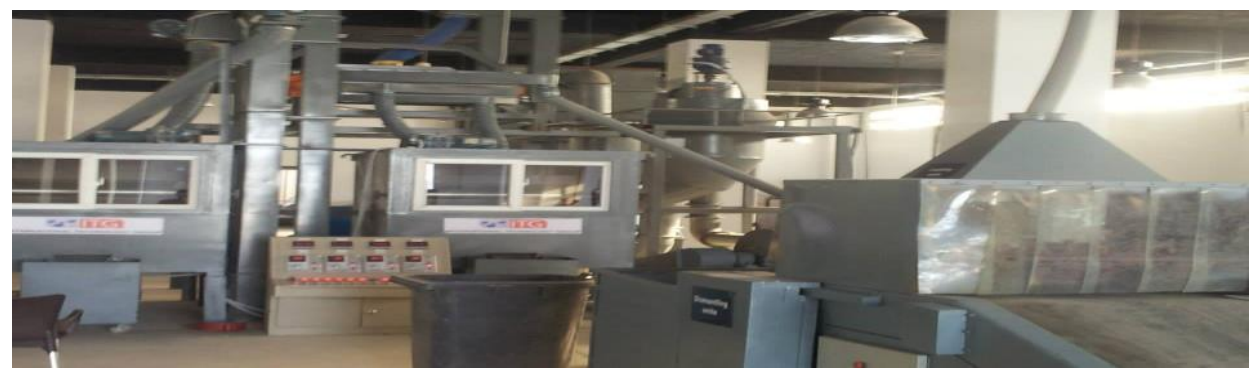

Figure 10.A: E-waste recycling Line 
J. Environ. Sci.

Institute of Environmental Studies and Research - Ain Shams University

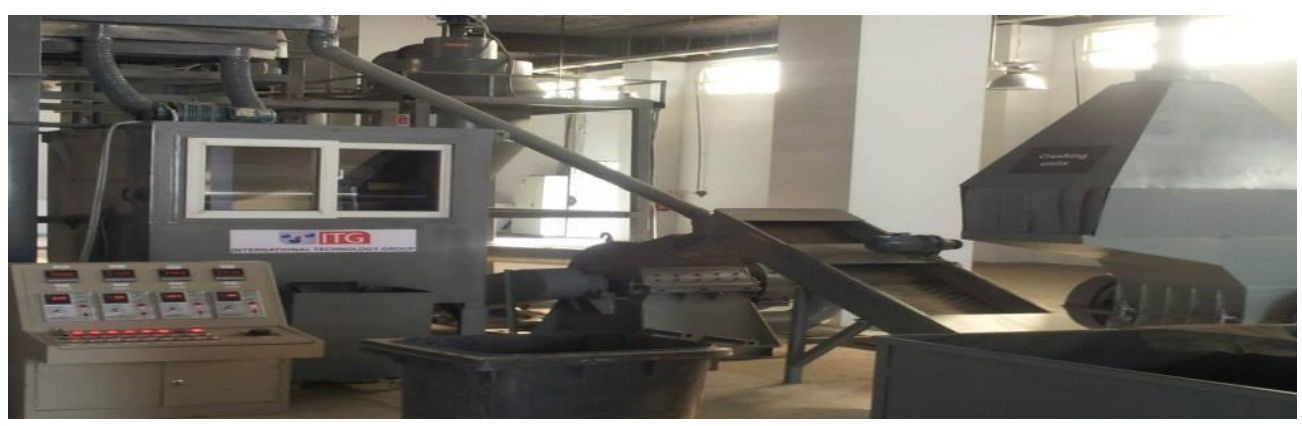

Figure 10.B: E-waste recycling Line

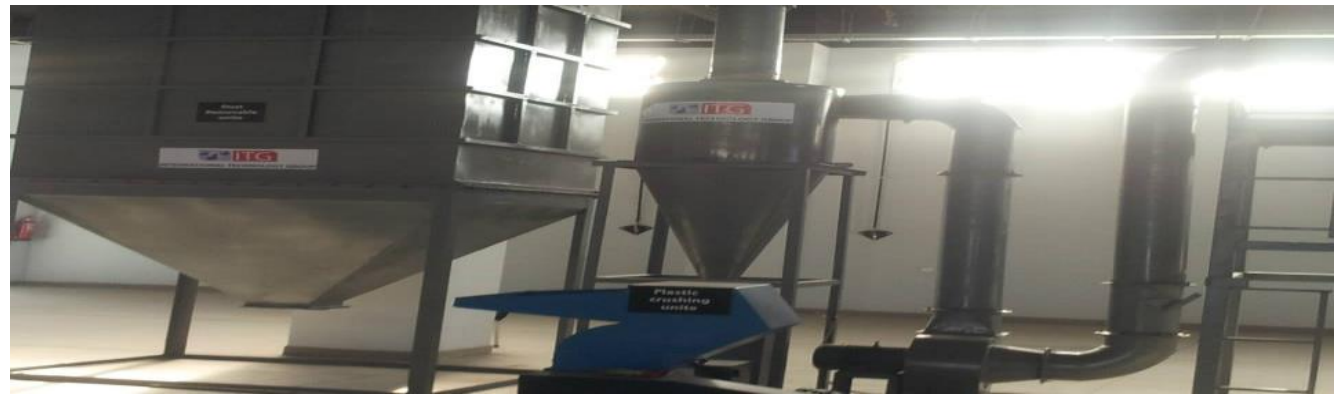

Figure 10.C: E-waste recycling Line

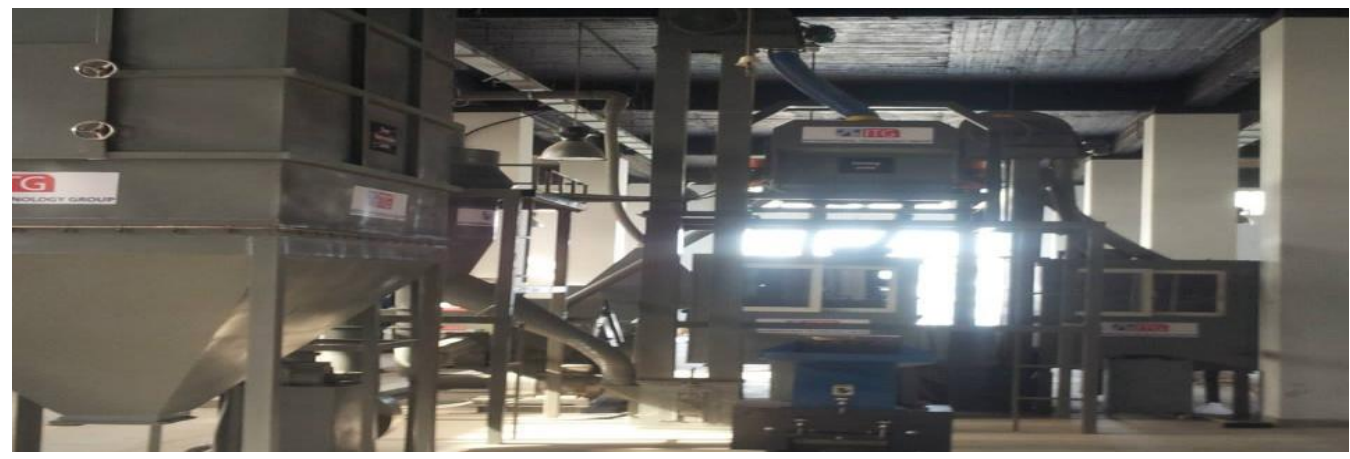

Figure 10.D: E-waste recycling Line 


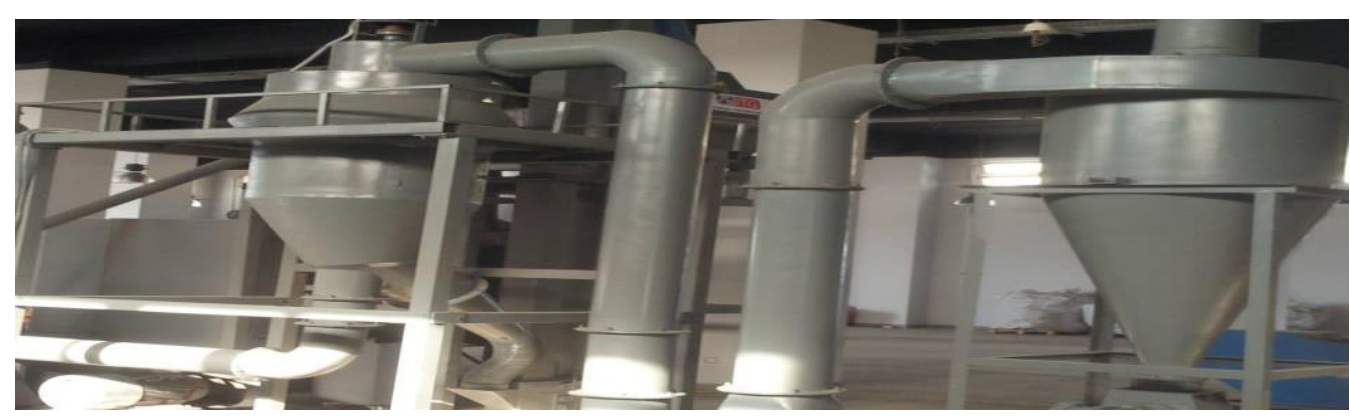

Figure 10.E: E-waste recycling Line

Factory production line consists of four phases, the first begins with a "cracker" until it reaches the metal thickness to $4 \mathrm{~cm}$, then begin "grinding metal" process to become in the form of a 2-inch or $3 \mathrm{mM}$ meters almost powder, then the "Sichaelor", a pneumatic pumps to assemble at least density in place and the largest in the other place, and the third stage of the analysis, by introducing the article in the "sieve vibration", and then the fourth and final stage, which is to separate the metals mixture from each other such as gold, silver platinum and other precious raw materials stage in place by electric charges, and plastic elsewhere.

The role of the factory stops at this point and did not Separates metals, which shall send them to the German organization, to undertake this stage is sent to a factory once again, indicating that the factory making the creation of a new line of specialized process first season interests factory strategy is which.

\section{Nasreya Hazardous Waste treatment center for Final \& Safe Destination of Hazardous Waste in Alexandria:}

The vault receives approximately 40 tons per year of electronic waste, 
Just 60 kilometers from the heart of Alexandria located processing and burying hazardous waste project, which is the only place in Egypt and the second in the Middle East, hazardous waste, and the idea of the project started in 2000 by Egyptian Finnish cooperation.

Hazardous Waste Management in Alexandria project is an Egyptian Finnish cooperation project was established for the design and construction of nonhazardous organic waste treatment system and activate the Egyptian Environmental Law No. 4 of 1994. The industrial hazardous waste in Alexandria Project Management is the result of environmental efforts to the province of Alexandria as a conservative, which includes $40 \%$ of the industry $50 \%$ of the petroleum industry in Egypt.

It has been entrusted with the task of implementing the project for the province of Alexandria, where unit-hazardous industrial waste management are working under the leadership of the province directly. Hazardous Waste was signed between the Ministry of State for Environmental Affairs and the province of Alexandria and USAID Finnish draft agreement in February 1999.

Mr. Minister / Governor of Alexandria decision No. 416 of 2000 to establish a unit for the management of hazardous industrial waste in Alexandria has been issued to be responsible for this activity during and after the completion of the project.

The work of the two studies to assess the environmental impact of the knowledge (Alexandria University and specialized consulting offices) study showed the validity of the site from an environmental perspective. 
The work of the topographic survey of the site of the new knowledge of the consulting firm, as well as engineering designs for the site was the work of the chemical analysis of soil borings and analysis of water, succession by a factor of Faculty of Engineering - Alexandria University showed the validity of the site analysis.

Dealing with hazardous waste and disposed of the first phase of the project depends on the policy of burying hazardous waste buried padded cell layers, insulating and this Vault is connected lakes lined steaming also lining dielectric function is to withdraw any nominated may result in cell burial.

Site Description:

The site is surrounded by a wall of bricks from all directions length of 500 meters and width of 300 meters and a height of 15:00 and has two gates 17:00 display a component of the following:

1-Security Room.

2-Administrative building consisting of ground on the role of space $(250 \mathrm{~m} 2)$ with six administrative offices and a chemical plant and the Chamber of balance.

3-Building Campaign mechanical garage includes office and workshop welding rubber and garage Lauder and two cars, one transfer fluids and other solid waste and a fork.

4-Truck scale load of 40 tons.

5-Landfill quilted insulation layers. The cemetery occupies $14,000 \mathrm{~m} 2$ flat depth of 2 meters in line of what is the case in the European system in this field. 
6-Lakes evaporation and number four with an area of $5000 \mathrm{~m} 2$ which is lined in the same sequence layered dielectric and connected to a landfill by pipeline.

7-Wash station where the waste is cleaned waste transport vehicles after delivery and before leaving the facility.

8- Processing Unit chemical physics.

9-Unit Inorganic waste storage.

10-Unit organic waste storage.

11-Unit vulcanization residues.

12-Wells to monitor groundwater depth of 50 meters.

13-Electricity distribution room supplement the security room in the western sea.

\section{4-Electrical generator.}

15-Piston for pressing drums sheet after treatment.

16-Quern for plastic recycling.

17-Two (2) incinerator for thermal treatment of organic wastes.

18-Unit waste containing mercury processing (compact fluorescent lights).

The site is equipped with equipment required by the operational phase, such as the loader and liquid hazardous waste containers and vehicles of liquid and solid hazardous waste and special characters match the requirements for transporting hazardous waste transfer mobilize.

It was a chemical processing plant site to initial analysis has been strengthened laboratory materials and laboratory instruments and tools to prevent occupational health required for operation. 
Dated 24/5/2004 has been initiated in the operation of the management of hazardous waste were dealing with a number of companies inside and outside Alexandria.

Create a database of hazardous waste:

1-A questionnaire has been to collect information and data on hazardous waste in various industrial design activities.

2-The development and implementation of monthly plans and periodically to limit 3-the hazardous industrial waste volumes through field visits to industrial companies.

4-It is reported for each visit.

5-A file is opened for each company, including all the data that has been collected.

6-The program is designed on a computer and was fed with data that had been collected from the companies aphid.

\section{Expected results of the project:}

Compliance with local policies: It is expected that the project complies with national and local policies as the Governorate of Alexandria contracted with Onyx Management Company ordinary household waste and the contract did not include industrial hazardous waste collection.

Access to patients the economic and financial system of the key objectives in the development and operating unit to maintain and develop the management system.

Impact on the environment: It is expected to be the impact on a remarkable environment where it will be hazardous waste trading within the facilities better and will waste storage and thus improve the environment and industrial 
facilities where the industry will avoid out any remnants of hazardous sewage and therefore less water pollution and less impact on the sewerage network is also expected to gradually least hazardous waste buried with regular waste.

On April 2010, the project of management of waste containing mercury (Fluorescent lamps) in collaboration with the State of South Korea to complete the hazardous waste management system in Egypt started By establishing the first unit of its kind to treat the residues of fluorescent bulbs containing mercury element, which is dangerous to human health and its environment is highly toxic and its presence in the air causes serious respiratory and neurological diseases.

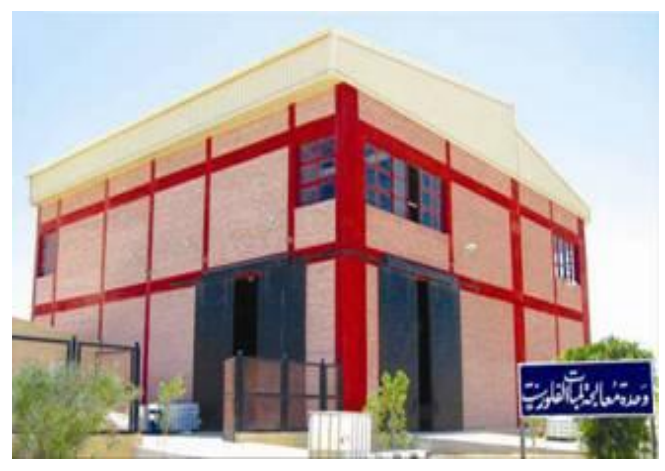

Figure 1.A

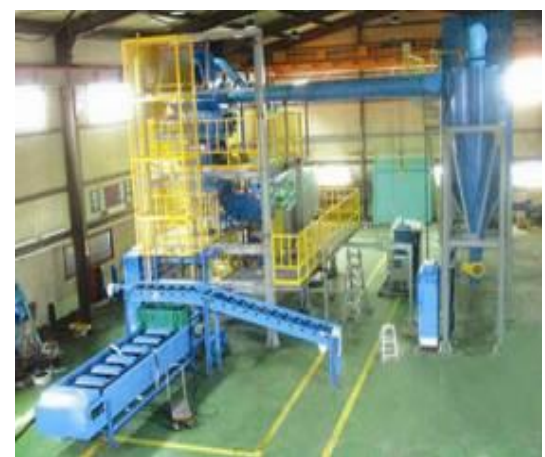

Figure 1.B

Figure1: Fluorescent lamps chamber

On 12/5/2010 Supply and operation of incinerator for heat treatment of 
organic waste.

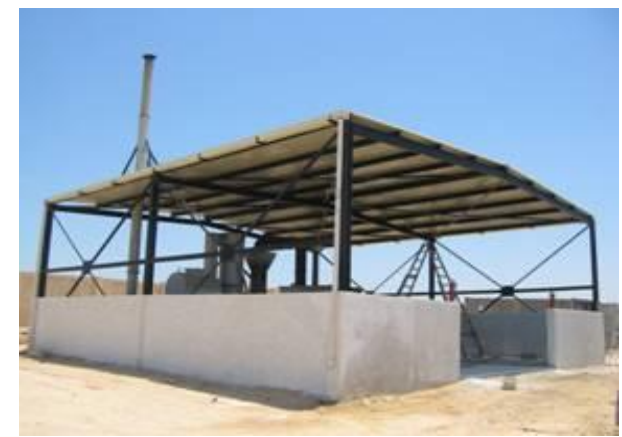

Figure 2.A

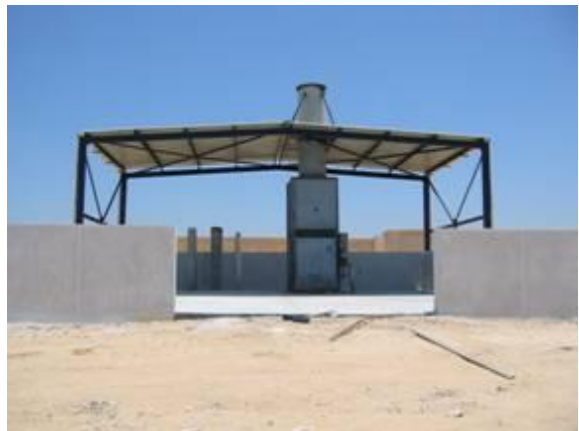

Figure 2.B

Figure 2: incinerator for heat treatment of organic waste.

On June 2010, a team of hazardous waste management and Environmental Affairs Agency of South Korea was trained to operate and maintain the mercury-containing waste unit (fluorescent lamp).

On October 2010 the supply and installation of a plastic recycling machine.

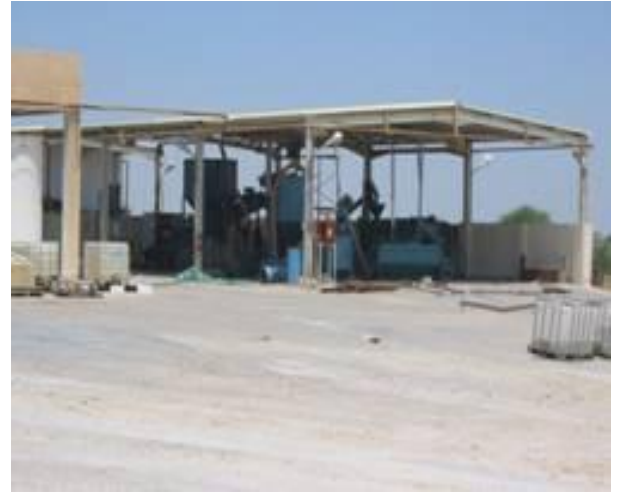

Figure 3.A

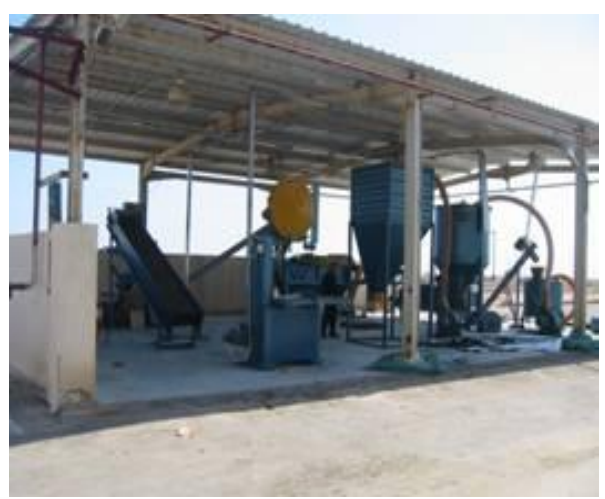

Figure 3.B

Figure 3: plastic recycling machine. 
J. Environ. Sci.

Institute of Environmental Studies and Research - Ain Shams University

\section{RECOMMENDATIONS}

Governments need to encourage projects which seek to develop green sources of energy. Much effort to adopt green strategies is initiated by individuals or non-governmental institutions which do not often receive much support from their governments. By supporting these organisations, the government will help to reduce E-waste.

International need to organisations and donor agencies working to bridge the digital gap in countries ensure those recipient organisations in Africa and other developing nations have the capacity to recycle the refurbished computers they ship. If there is no access to such facilities in their vicinity, alternative solutions need to be sought.

As most organisations and individuals receiving computers in developing countries may not be fully aware of the consequences of E-waste or the need for green options, partner organisations abroad need to provide appropriate support on E-waste management through education.

Individuals also have a responsibility in adopting and promoting green IT in order to reduce E-waste. Networks of individuals in communities interested in promoting green IT could be formed to act as a local neighbourhood watchdog to prevent E-Waste disposal. This could be done by being involved in green IT education and encouraging others to recycle E-waste. 


\section{REFERENCES}

Asante KA, Agusa T, Biney CA, Agyekum WA, Bello M, Otsuka M, Itai T, Takahashi S, and Tanabe S. (2012): Multi-trace element levels and arsenicspeciation in urine of e-waste recycling workers from Agbogbloshie, Accra in Ghana. Science of the Total Environment 424, 63-73.

Ayesha and Anjum, (2013): Green computing: E-waste management through recycling. International Journal of Scientific \& Engineering Research, 4(5):1103.

Borthakur A, Sinha K.(2013): Generation of electronic waste in India: current scenario, dilemmas and stakeholders. Afr J EnvironSci Technol ,7(9):899-910.

Cobbing M.(2008): Toxic tech: not in our backyard [Internet]. Amsterdam, The Netherlands: Greenpeace International; 2008 Feb http://www.greenpeace.org/ international/Global/international/planet-2/

Environmental Protection Agency. (2008). Electronics Waste Management In The United States Approach I. Washington, DC.

Guidelines for e-waste management in Bangladesh, Dhaka, Bangladesh: Environment and Social Development Organization; 2012 Dec , $40 \mathrm{p}$.

Herat S and Agamuthu P.(2012): E-waste: a problem or an opportunity? Review of issues, challenges and solutions in Asian countries. Waste Manag Res,30(11):1113-29.

Hossain S, Al-Hamadani SMZF, and Rahman T. (2015): E-waste: A Challenge for Sustainable Development Journal of Health \& Pollution, 5-9.

Jain A. (2010): E-waste management in India: current status, emerging drivers and challenges [Internet]. Regional Workshop on Ewaste/WEEE Management,; Osaka, Japan. New Delhi, India: IRG Systems South Asia, 13 p.

Kiddee P, Naidu R, Wong MH.(2013):Electronic waste management approaches: An overview .Waste Management 33 : 1237-1250. 
Needhidasan S , Samuel M and Chidambaram R.(2014): Electronic waste an emerging threat to the environment of urban India Journal of Environmental Health Science \& Engineering, 12:36.

Puckett J, Byster L, and Westervelt S. (2002): Exporting Harm: The HighTech Trashing of Asia, The Basel Action Network (BAN) and Silicon Valley Toxics Coalition (SVTC), http://www .ban.org/Ewaste/technotrashfinalcomp.

Qu W, Bi X, Sheng G, Lu S, Fu J, Yuan J, and Li L. (2007): Exposure to polybrominated diphenyl ethers among workers at an electronic waste dismantling region in Guangdong, China. Environment International 33, 1029-1034.

Sinha-Khetriwal D.(2002): The management of electronic waste: a comparative study on India and Switzerland, M.S. thesis, University of St. Gallen, St. Gallen, Switzerland.

Sum EY.(1991): The recovery of metals from electronic scrap. J Minerals Metals Mater Soc ,43(4):53-61.

Uddin J .(2012): Journal and Confrence Paper On (Enviornment) E - Waste Management. IOSR Journal of Mechanical and Civil Engineering (IOSRJMCE), 2(1):25-45.

UNEP, European Commission, BCC. 2013.

Widmer R, Krapf HO, Khetriwal DS, Schnellmann M, and Boni H.(2005): Global perspectives on e-waste. Environ Impact Assess Rev, 25(5):436-58.

Wong MH, Wu SC, Deng WJ, Yu XZ, Luo Q, Leung AOW, Wong CSC, Luksemburg WJ, and Wong AS.(2007):Export of toxic chemicals - review of the case of uncontrolled electronic-waste recycling. Environmental Pollution 149,131-140.

Xing GH, Chan JKY, Leung AOW., Wu SC, and Wong MH. (2009): Environmental impact and human exposure to PCBs in Guiyu, an electronic waste recycling site in China. Environment International 35, 76-82. 
Zhang S and Forssberg E. (1997): Mechanical separation-oriented characterization of electronic scrap. Resources, Conservation and Recycling 21, 247-269

Zhao G, Wang Z, Dong MH, Rao K, Luo J, Wang D, Zha J, Huang S, Xu Y, and Ma M. (2008): PBBs, PBDEs, and PCBs levels in hair of residents around e-waste disassembly sites in Zhejiang Province, China, and their potential sources.Science of the Total Environment 397, 46-57.

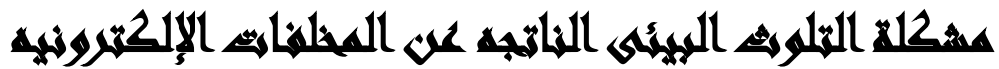

\section{[r]}

$$
\begin{aligned}
& \text { سلوى حسين عبد الفتاح الرملي(') - محمد عبد العزيز محمد(؟) - محمد أحمد زكي فرحات }
\end{aligned}
$$

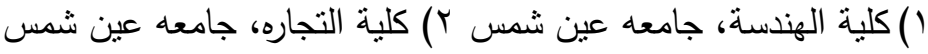

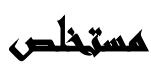

تهدف الأدوات الإلكترونية لجعل حباتتا أكثر سعادة وأكثر بساطة، ولكنها تحتوي على المواد

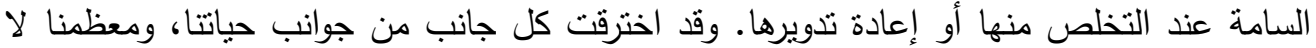

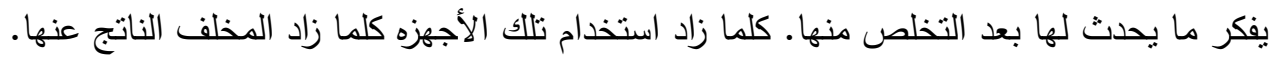

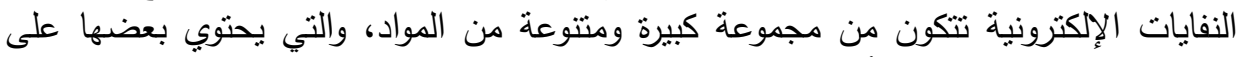

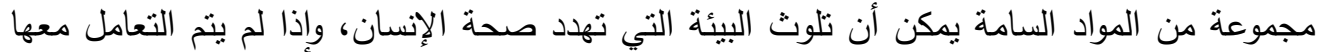
بشكل مناسب. ونتشل طرق التخلص من النفايات الإلكترونية مكب النفاد النفايات وحرقها، وكلاهما بشكل مخاطر تلوث كبيرة. 